\title{
Innovation in Culture and Arts Learning in the Digital Era
}

\author{
Riyadi Sap Dewi Murni ${ }^{1, *}$
}

\author{
${ }^{1}$ Graduate School of Art Education, Yogyakarta State University, Yogyakarta 55281, Indonesia \\ *Corresponding author. Email: dewimurnipink@gmail.com
}

\begin{abstract}
Cultural digitalization is a concept of utilizing information and communication technology to enhance the effectiveness in the field of culture, especially in terms of managing, documenting, and disseminating information and knowledge from cultural elements. The development scope of digitization on culture includes cultural elements, namely religious systems, social systems or social organizations, knowledge systems, languages, arts, livelihood systems or economic systems, and technological systems. Culture and arts learning must provide appreciative and creative experiences and contribute to improve the students' knowledge, morals, and skills in the future. To achieve these expectations, creative and innovative efforts or learning models are needed in developing strategies according to student characteristics. The development and utilization of information technology-based culture or digitization are very significant to be implemented in preserving, maintaining, and developing cultural values as self-identity and wealth of the Indonesian nation.
\end{abstract}

Keywords: innovation in education, culture and arts, digital era

\section{INTRODUCTION}

The advances in science, technology, and arts have made changes in almost all aspects of human life. This fact has made various layers of society aware of trying to always improve the quality of Human Resources (HR) in the field of science and technology. The issue of human resources currently has gained special attention in the development of national education in this country. On the other hand, a shift in a learning paradigm initially emphasizes the teaching process which is content oriented and abstract; therefore, learning tended to be passive. Now, shifting to a new paradigm in learning marked by the existence of a problem or case based-learning process is more contextual, and students are required to be more active in learning and developing subject matter constructively by utilizing various available learning resources.

In line with the shift in a learning paradigm, there has also been a paradigm shift in culture and arts learning. In the past, culture and arts learning was oriented to the ability to work independently or the high demand for skills. Now, culture and arts learning at public schools is oriented to the ability to make expressions by working and appreciating the aesthetic values of arts to witness the maximum experience of arts.

Along the way, culture and arts learning is faced with various problems in the field. These problems include (a) availability, distribution, and quality of teaching staff; (b) inadequate learning facilities; (c) short time allocation in learning; and (d) frequently changing learning materials. In addition, there are more specific issues in culture and arts learning, such as problems with the varied student interests and talents and physical or social problems that do not accommodate the implementation of arts and culture learning at schools.

The cultural richness of Indonesia, spreading throughout the archipelago, has been a philosophy of life for indigenous communities for centuries. Even before the independence of this country, culture was the foundation of life for every indigenous society in Indonesia. For this reason, a number of Indonesian cultural instruments have been recognized by the world through UNESCO for both material and non-material cultures. This recognition is not only a matter of pride but things to be employed and developed; thus, culture can provide benefits spiritually as aspired by the founders of this nation. The readiness of Indonesia as a 
cultured nation is tested for its endurance through the flow of globalization and limitation of the global situation due to the COVID-19 pandemic as it is today.

In the past, when the development of communication and information technology was not as rapid as it now, the values of Indonesian cultural identity were still held tightly by the society. However, nowadays, when foreign identity values easily and quickly enter this nation through information transformation, the values of Indonesian cultural identity are slowly eroded [1].

According to Sukmana [2], a concept of digitalization is the process of transferring media from printed, audio, and video to digital forms. Digitalization is carried out to create digital document archives, to run a photocopy function, and to develop systems. It requires equipment such as computers, scanners, source media operators, and supporting software. The printed documents can be transferred to digital forms with the help of document scanning programs such as Adobe Acrobat and Omnipage. Digitalization is further developed with the concept of transferring tacit knowledge, which is personal, specific, and generally difficult to formalize and communicate to other parties into explicit knowledge, i.e. knowledge that has been formulated and presented in written forms such as regulations and literature. This explicit knowledge is manifested in the form of documents that are well managed using information and communication technology.

This documented knowledge can be used as learning materials for each generation; therefore, the process of transferring information and knowledge can run well.

According to C. Kluckhohn's [3], cultural elements consist of seven aspects, namely religious systems, social systems or social organizations, knowledge systems, languages, arts, livelihood systems or economic systems, and technological systems.

In the digital era, many changes have occurred in almost all life aspects. One of them is the use of digital media to create a work of art. A long time ago, creating works of art was done by capturing nature through a painting using a vase and brush.

Along with the fast development of technology, people find ways to do a job quickly and efficiently. The impact of this digital technology has also influenced the field of culture and arts, which previously tended to make innovations on stage or performance shown to the audience. Therefore, during the COVID-19 pandemic, the role of multimedia is not merely a form of documenting performances, but also a means for introducing the performing arts to audiences, so that performing arts through multimedia or digital media must be able to accommodate both artists and audiences. That is why a complementary synergy is needed between art performances and digital media that make audiences engaged to enjoy the show.

At this time, art is no longer soul needs but has become life needs. With electronic media such as computers, cameras, video recorders, art has changed a lot. Art is not only considered as a form of expression of the soul that creates it but also seen to hold a million meanings and 'interests'. Also, with the help of tools, art is no longer a pure form of the soul expression, but it is able to provide a million meanings and 'interests'. With the use of computerized tools, art becomes an instant thing that can be made by anyone. Especially, when the COVID-19 pandemic has been a global issue, almost all sectors are affected, including the field of arts and culture. Both artists and connoisseurs of arts and culture must adapt to enjoy culture and arts performances in current conditions, which usually could attract mass visitors. Because the impact of the pandemic is considered high in certain areas, there must be health protocol in enjoying and holding events of culture and art performances. This is what makes arts and culture performances require serious innovation through multimedia; it needs collaborations between culture or arts performers and actors/artists in the photography and multimedia fields.

This development must be immediately anticipated by the educational program in the field of culture and arts, to provide a facilitator of culture and arts performances in these conditions.

Teachers and students must be ready to face the conditions if something worse happens later. Hence, they will be ready to handle this situation. Even, it is an exact time that creativity formed by educational institutions or schools plays a significant role to develop culture and arts education during the COVID-19 pandemic or to collaborate with the field of multimedia science. This is a real challenge that must be faced and handled to save the sustainability of the nation's culture and arts which are at stake in the current conditions.

With an approach that emphasizes the teacher function as a guide for students, it can widen space for student creativity, which encourages them to be a preserver of the nation's culture and arts.

The development of art and design to become more global and advanced cannot be denied because it gives a positive contribution to our lives. Also, it due to a change that is a must and does not wait for our readiness.

Using electronic versions of brushes, filters, and magnifiers is a kind of "neographer", producing images with no conventional photographic tools. Additionally, digital artists may manipulate scanned images, paintings, collages, or lithographs, and any of the techniques mentioned above in combination. 
The artists also use other sources of electronic information and programs to create their work. Therefore, in this digital era, they must use them appropriately and wisely to experience the benefits.

The creative concept will determine the production and marketing concepts such as conducting research on the intended market demand in preparing creative ideas, and careful planning because it deals with promotion, distribution, and delivery of cultural artists' works.

The digital era has provided a major influence on work patterns, production, and distribution in the culture and arts industries, both locally and globally, and on practitioners, such as artists, agencies, producers, event organizers, quality of work, taste on art works, and other infrastructures.

\section{LITERATURE REVIEW}

\subsection{Definition of Digital Learning}

Munir [4] said that information and communication are parts of the rapidly developing technology that affect life and changes in the way of living and daily activities, including the field of education. Education is experiencing fast development in digital learning. By applying the advance, the development of information technology and educational communication can reach all levels of society. Science with technology is a pioneer in the digital era developments, and education is required to achieve abilities in the field of technology with its needs or technological literacy.

\subsection{Digital Generation}

Education expert, Mark Pensky in Mardina [5], argues that there are two digital generations, namely digital natives and digital immigrants, elaborated as follows:

\subsubsection{Digital Natives}

Digital Native is a generation born in the digital era. This generation is dominated by computers, video games, cell phones, and various kinds of devices produced in the digital age. The generation of digital natives considers communication devices as an integral part of life that cannot be separated from technology.

\subsubsection{Digital Immigrant}

Digital Immigrant is a generation born before the digital era and then attracted by technology to use it.

\subsection{Digital Learning Potential}

According to Kenji Kitao in Munir [6], three digital learning potentials which can be utilized in everyday life include a means of communication, a means of information access, and education or learning media.

\subsubsection{Potential in the Means of Communication}

By using digital learning, people can communicate anywhere quickly such as using e-mail and online chat. Using conventional communication media is more expensive because the farther the distance and the more information conveyed, the more expensive it will be.

\subsubsection{Potential in Internet Access}

Learners can access various references both in the form of research results and articles from various fields. With internet access, learning can be done online using computers in interacting with learning resources such as materials and teachers, who foster or are responsible for the learning process. With digital learning, learners have options or alternatives to joining virtual face-to-face classes.

\subsubsection{Potential in Education or Learning Media}

The technology development that spreads fast throughout the world has been explored by various fields, one of which is education and learning to develop software and to improve the quality. Electronic learning materials are developed and uploaded to be accessed through digital learning and socialized in the wider community.

\section{RESEARCH METHOD}

The research used a qualitative descriptive method. The data collection employed a literature study technique and previous research studies with a library research method or approach. Literature studies can be interpreted as a series of activities related to methods of collecting library data, reading and taking notes, and processing research materials [7].

This study employed a library research approach. According to Zed [7], library research provides special characteristics: (1) the research deals directly with texts or numerical data, not eyewitness, several incidents, people, or other objects; (2) the data are ready-made, meaning that the research deals directly with data in the library; (3) the data in the library are generally a secondary data source; the researcher obtains secondhand data, not first-hand found in the field, and (4) the condition of the library data is not divided by time and space.

The data source for the research consisted of books, journals, and internet sites related to the selected topic. The data collection was carried out by reviewing and/or exploring several journals, books, and documents (both printed and electronic) as well as data sources and or 
other information deemed relevant to research or study. The researchers analyzed the data using a content analysis method. This analysis was used to obtain valid inferences and could be re-examined based on the context [8].

\section{FINDINGS AND DISCUSSION}

The view indicating that culture and arts learning is not important is a complaint that has repeatedly arisen. In some cases, a culture-and-arts subject is considered as a curriculum load. The subject will be considered significant when there is a competition or festival that requires schools to send their students as participants. Of course, it is also impossible to include all students to be the participants. Only students who with interests and talents are selected to join the competition.

Another fact is also indicated by an attitude shown in the lesson provisions of the national final exam which emphasizes certain subjects. This may create a people's interpretation that the subject of arts and culture is "not significant". Other cases have also been revealed and it is not a secret that in the final grades of primary, junior high, and senior high schools, there has been a reduction in some subjects to be no longer taught, and there are only a few subjects tested in the national exam. The same thing also happens in other cases such as a matter of continuing studies, where the concern is the learning outcomes of certain subjects. There is even a heartbreaking thing that an indicator to classify a lowachieving student is seen from the marks or scores of exact science subjects only, such as Natural Science and Mathematics.

Regarding the existence of culture and arts subjects in the last few years, at least since the subject was included in the national curriculum, anomalies have begun to be felt in some school levels from elementary to high school. Culture and arts education must continue to exist, and even during the COVID-19 pandemic, it creates a moment for culture and arts to make a real contribution. Utilizing multimedia can provide opportunities for students who may be less talented in culture and arts but have an ability in the multimedia field to complement each other. It challenges teachers to guide and provide space for students to hone their creativity in the fields of culture and arts and multimedia. It can be uneasy, but with consistency and willingness to maintain culture and arts in national learning, everything can be well managed and carried out.

Based on the results of the observation, the cultureand-arts subject is only targeted for children who are interested in and talented. In other words, the subject is implemented to accommodate the artistic talents of a few students, who can collaborate with those with an interest in multimedia. Regarding this, it is understood how important the role of arts and culture is in conditions like today. This makes a difference in the view that with the many challenges, the roles of culture, arts, and multimedia make it compulsory for all students to engage and study seriously in this subject. Such an assumption is what makes the arts and culture subject is positioned as the raw material for intellectual empowerment and creative potential of students. In fact, the demands on the abilities that must be acquired by students are "free", creative, and innovative thinking, which is also regarded as the mission and vision of national education. The interpretation of the significance of certain subjects, currently, makes arts and culture lessons one of the important subjects in creating and expressing an object at local and global levels through collaborations with multimedia, which makes something promising for a better future. That is why, it should be considered essential to improve the learning quality in the culture and arts subject at schools. Actually, there is a more urgent problem in the implementation of culture and arts learning, i.e., teacher professionalism. Culture and arts teachers must be smart and creative to cope with the various problems found in culture and arts learning.

To answer these various problems, teachers can employ many available learning tools and resources. Of course, this is not easy to do by the culture and arts teachers, without equipping them with an understanding of universal culture and arts insights. Therefore, culture and arts learning must be understood as the basic values of science, which are technical-practical, theoretical, and psychological. For this reason, all teachers and students need to make innovations in managing a constructive learning process. In this era of advanced knowledge, technology, and arts, it is hoped that the learning process will be more meaningful. Indeed, arts and culture learning in some primary and secondary schools is still conducted conventionally in the sense that its orientation is limited to skill education. Conventional learning is considered inappropriate according to the concept of education with the principles of flexibility, responsiveness, activeness, and creativity. Therefore, culture and arts teachers have to start to interpret and redefine the paradigm of learning. In this case, they are expected to have a desire to respond to the global culture development in which the domain of culture and arts education focuses more on the growth and development of critical attitudes towards emerging cultural phenomena.

Furthermore, arts teachers want students to acquire the ability to use their knowledge, experience, and talents creatively through various activities or culture and arts skills to preserve and uphold national cultural values that are slowly eroded by advances in science, technology, and arts. To learn culture and arts, there are at least three main arts that are learned, namely visual arts, dance, and music. Therefore, culture and arts 
teachers must acquire (1) a sense of visual art, being responsive or sensitive to visual symptoms or aesthetic forms, (2) a sense of auditory art, being responsive to various audio symptoms covering sound dynamics, and (3) a kinesthetic sense, being ready to respond to various types of material movements. If the three things above are well achieved, the arts and culture teachers will be able to provide enormous opportunities in developing and finding creative ideas to teach arts and culture, which are more meaningful and excellent in quality.

Advances in science, technology, and arts are new challenges for arts teachers. This progress requires teachers to improve their personal, social, pedagogical, and professional competencies in terms of learning. These competencies will then place the teachers in a new paradigm of a learning process. The teachercentered method applied so far with the assumption that the teacher knows all and the students do not have any single idea has been replaced by a student-centered approach. Students become the center of attention in learning, while the teachers function as facilitators, mediators, motivators, and inspirers.

The implication of the learning approach and this paradigm shift in learning is that teachers and students learn from each other and work together. Students are free to express their ideas and thoughts with no hesitation. Teachers must also be willing to learn from students, particularly those with advantages in certain fields of knowledge. Advances in science, technology, and arts are widely accessed by most students. With a few clicks of the mouse, they have browsed information and knowledge from many parts of the world. Therefore, teachers must be open and willing to learn from them. If this is not initiated by the teacher, he/she will be left behind.

Indonesia is famous not only for its abundant natural resources but also for its plentiful arts and culture. This wealth is indicated by a huge number of ethnic groups, i.e. 1,340 , taken from the 2010 census data by Indonesia Statistics. Each ethnic group has more than one kind of traditional art, so that it provides higher diversity than the number of ethnic groups. With the great results of creation, feel, and will in various customs, cultures, and arts owned by the Indonesian people, other nations have always noticed them. From the great number of creations and works by ethnic groups in Indonesia, 77 cultural works are registered as Indonesian intangible cultural heritage, after going through verification and assessment processes by the expert team of the Ministry of Education and Culture of the Republic of Indonesia through the Directorate of Internalization of Values and Cultural Diplomacy. Six of them (wayang, keris, batik, angklung, Saman dance, and Papua Noken) have been designated as Indonesian cultural heritage by UNESCO. This achievement should be something to be proud of, especially how to explore this potential to improve the welfare and prosperity of the community who creates the arts [6]. To utilize and develop the existing potential for the benefit of economic welfare and knowledge transfer from cultural elements, this sophisticated era positions the information and communication technology as an absolute must to be utilized. In this case, the digitalized scope of culture refers to the cultural elements stated by C. Kluckhohn [3].

\section{CONCLUSIONS}

Based on the literature review of articles and examples of cultural element digitalization, the conclusions are drawn as follows:

- In the context of a paradigm shift in learning, the learning of culture and arts must be able to provide appreciative and creative experiences and contribute to enhance the students' knowledge, attitudes, and skills in the future. To achieve these goals, creative and innovative efforts are needed in developing learning strategies or models according to their characteristics, such as utilizing multimedia. Thus, culture and arts learning are able to shape the students to be human beings who are ready to face life full of challenges in the global era.

- The development and utilization of information technology or digitalization-based culture are very crucial to be revived in preserving, maintaining, and developing cultural values as self-identity and wealth of this nation.

- The digitalization of culture does not stand alone but it is interconnected with other electronic fields. There are approximately four dominant fields, namely knowledge management systems, e-library, e-learning, and e-tourism. Therefore, the government and customary law communities must set a strategic plan or a road map that is clear, firm, and comprehensive so that preservation and conservation efforts are tangible and can be enjoyed by all stakeholders, e-business, and e-government.

- The development and preservation of information technology-based culture in Indonesia have so far been partial and slow; thus, many cultural elements are threatened with extinction. Therefore, the government and customary law communities must set a strategic plan or a road map that is clear, firm, and comprehensive so that conservation and preservation efforts are more tangible and can be enjoyed by all stakeholders. 


\section{REFERENCES}

[1] Mubah, A. Safril. Revitalisasi identitas kultural Indonesia di tengah upaya homogenisasi global [Revitalizing Indonesia's cultural identity in the midst of global homogenization efforts]. Global \& Strategis, Edisi Khusus, 2011. pp. 251-260. URL: http://www.journal.unair.ac.id/filerPDF/7\%20Safri $\underline{1 \% 20-}$

\%20Revitalisasi\%20Identitas\%20Kultural\%20Indo nesia\%20di\%20Tengah\%20Upaya \%20Homogenis asi $\% 20$ Global, $\% 20 \mathrm{ok}$.pdf

[2] Sukmana, Ena. Digitalisasi Pustaka [Digitalization of Libraries. Proceedings of the Seminar Peran Pustakawan pada Era Digital. vol. 16, 2005. URL: https://www.researchgate.net/profile/Ena-

Sukmana/publication/236965703 DIGITALISASI PUSTAKA/links/0deec51a80c1dce616000000/DI GITALISASI-PUSTAKA.pdf

[3] Kroeber, Alfred Louis, and Clyde Kluckhohn. Culture: A critical review of concepts and definitions. Papers. Peabody Museum of Archaeology \& Ethnology, Harvard University (1952). pp. 167-8.

[4] Munir, M. Pembelajaran digital [Digital Learning]. Bandung: Alfabeta, 2017. p. 1.

[5] Mardina, Riana. Potensi digital natives dalam representasi literasi informasi multimedia berbasis web di perguruan tinggi [The potential of digital natives in the representation of web-based multimedia information literacy in universities]. Jurnal Pustakawan Indonesia 11(1), 2011. URL: https://journal.ipb.ac.id/index.php/jpi/article/view/5 $\underline{264 / 3681}$

[6] Munir, M. Pembelajaran digital [Digital Learning]. Bandung: Alfabeta, 2017. pp. 7-9.

[7] Zed, Mestika. Metode Peneletian Kepustakaan [Library Research Methods]. Yayasan Obor Indonesia, 2004.

[8] Krippendorff, Klaus. Analisis Isi: Pengantar Teori dan Metodologi [Content Analysis: An Introduction to Theory and Methodology]. Jakarta: Citra Niaga Rajawali Press, 1993. 